First Wanita, Ashari, Nurpaida - Mengukur Kepuasan Costumer Terhadap Kualitas Layanan Sistem Informasi Perpustakaan Stmik Akba Menggunakan Metode Kano

\title{
MENGUKUR KEPUASAN COSTUMER TERHADAP KUALITAS LAYANAN SISTEM INFORMASI PERPUSTAKAAN STMIK AKBA MENGGUNAKAN METODE KANO
}

\author{
First Wanita $^{1)}$, Ashari $^{2}$, dan Nurpaida ${ }^{3)}$ \\ ${ }^{1,)}$ Sistem Informasi STMIK AKBA \\ STMIK AKBA Makassar \\ ${ }^{2)}$ STeknik Informatika STMIK AKBA \\ STMIK AKBA Makassar \\ ${ }^{3)}$ Sistem Informasi STMIK AKBA \\ STMIK AKBA Makassar \\ e-mail: $\underline{\text { riri.fw@email.com }}{ }^{1)}, \underline{\text { ashari.akba36@email.com }}{ }^{2)}, \underline{\text { nurpaida17@gmail.com }}^{3)}$
}

\begin{abstract}
ABSTRAK
Perpustakaan merupakan salah satu faktor penentu keberhasilan bagi mahasiswa dalam melaksanakan studinya karenanya tuntutan layanan system untuk perpustakaan juga semakin tinggi, dengan harapan setiap informasi atau koleksi yang dicarinya dapat diakses dengan cepat, tepat, mudah dengan kualitas yang tinggi. Oleh karena itu penelitian ini dilakukan untuk mengukur seberapa besar kepuasan pengguna terhadap kualitas layanan system perpustakaan yang ada saat ini di STMIK AKBA, pengukuran terhadap system perpustakaan ini dilakukan dengan memanfaatkan metode kano. Dalam metode ini faktor kualitas terbagi ke dalam 5 kategori yaitu must be, one-dimensional, attractive, indifference dan reverse yang memiliki karakteristik dan tingkat pengaruh yang berbeda pada konsumen. Penelitian ini menggunakan kuesioner sebagai instrumen penelitian. Dari hasil pengkuran pengisisan kuisioner dari 3 responden system ini dinyatakan layak digunakan untuk mengukur kualitan layanan system informasi pepustakaan karena melihat hasil persentasi pada aspek-aspek pengujian terhadap tingkat kesesuaian responden mendapat respon yang baik dengan nilai $\geq 75 \%$ dan system ini juga dapat diketahui informasi mengenai kebutuhan yang diinginkan oleh pengguna agar nantinya bisa memberikan layanan yang susuai dengan yang diinginkan oleh pengguna.
\end{abstract}

Kata Kunci: Metode kano, kualitas, pengukuran, sistem informasi perpustakaan

\begin{abstract}
Library is one of the critical success factors for students in conducting studies hence the demand for services for the library system are also higher, with the hope of any information or collections are sought can be accessed quickly, accurately, easily with high quality. Therefore, this study was conducted to measure how satisfied users for service quality library system that exists today in STMIK CMR, a measure of the library system is done by utilizing the method of the canoe. In this method the quality factor is divided into five categories, namely must be, one-dimensional, attractive, indifference and reverse that has characteristics and different levels of influence on consumers. This study used a questionnaire as a research instrument. From the results of taking the measurements filling the questionnaire of 3 respondents system was declared fit for use for measuring kualitan system service information library of seeing the results presentation on aspects of testing on the level of conformity of the respondents received good response with a value $\geq$ $75 \%$ and this system can also be known information about requirements desired by the user so that later can provide a service that corresponds to that desired by the user.
\end{abstract}

Keywords: Methods canoe, quality, measurement, information systems library

\section{Pendahuluan}

Dewasa ini, pesatnya teknologi informasi pada era globalisasi saat ini membuat kebutuhan akan informasi adalah mutlak yang harus terpenuhi dalam kehidupan manusia. Pemanfaatan informasi tersebut tentunya sudah merambah ke seluruh bidang atau aspek kehidupan. Bahkan penyampian informasinya pun semakin canggih seiring dengaan perkembangan teknologi informasi.

Teknologi informasi merupkan sarana penyedia ilmu pengetahuan yang terus digali dan di manfaatkan oleh siapa saja yang membutuhkannya. Bagi masyarakat luas pada umumnya dan kalangan mahasiswa khususnya, Hal ini tentu saja dapat memotifasi untuk dapat meningkatkan kualitas pelayanan demi memperoleh kemudahan dalam segala akti vitas untuk mencapai suatu tujuan. Pendidikan adalah kebutuhan yang paling mendasar bagi semua kalangan masyarakat dengan pendidikan dapat membawa kita lebih maju untuk bersaing dalam menghadapi era globalisasi. Pendidikan dapat kita raih dimana saja baik secara formal maupun non formal. Salah satu sarana kampus yang memberikan kita informasi serta pengetahuan yang lebih adalah perpustakaan.

Perpustakaan merupakan salah satu lembaga penyedia informasi yang dibutuhkan ketika mencari jawaban atas permasalahan berbagai dokumen seperti laporan peneltian, jurnal, atau bahkan buku teks. Berbagai dokumen tersebut tersedia di perpustakaan. Oleh karena itulah perpustakaan berperan penting sebagai penyedia informasi yang dibutuhkan mahasiswa.

Kualitas pendidikan di STMIK AKBA dapat ditingkatkan tidak hanya dengan meningkatkan sumberdaya manusianya sebagai pengajar akan tetapi harus diimbangi dengan tersedianya fasilitas layanan system informasi perpustakaan 
yang memadai. Dengan adanya fasilitas perpustakaan yang memadai, mahasiswa akan semakin termotivasi untuk semangat belajar

Kunci untuk mencapai kualitas adalah mengetahui siapa pengguna dan apa yang diinginkannya. Kualitas tidak ditentukan oleh satu atribut atau dimensi dari suatu produk atau jasa, tetapi ditentukan oleh beberapa atribut. Raymond, (2007)[1],. Dimensi dimensi tersebut terdiri dari : Kinerja, features, keandalan, kesesuaian, daya tahan, kemudahan perbaikan, keindahan, dan persepsi terhadap kualitas. Sedangkan subyek kualitas yang diterapkan pada kualitas layanan sistem informasi harus dapat mengidentifikasi suatu daftar dimensi-dimensi kualitas

Permasalahan yang muncul adalah apakah layanan yang diberikan perpustakaan sudah memberikan kepuasan kepada penggunanya. Permasalahan yang sering muncul dan dikeluhkan oleh pengguna dalam hal ini mahasiswadan dosen ialah pelayanan seperti memberikan informasi mengenai buku yang ingin dicari oleh mahasiswa atau dosen.. Salah satu metode yang digunakan untuk mngukur kepuasan pengguna terhadap layanan system informasi perpustakaan STMIK AKBA adalah dengan memanfaatkan metode Kano. Dalam Metode kano, menurut Khamseh(2011)[2] terdapat 5 kategori faktor kualitas yaitu must be, one - dimensional, attractive, indifference dan reverse yang memiliki karakteristik dan tingkat pengaruh yang berbeda pada konsumen. Adapun penelitian ini bertujuan untuk mengukur kepuasan pelanggan terhadap kualitas layanan Sistem Informasi perpustakaan dengan m enggunakan Metode Kano dengan mengidentifikasikan tingkat kepuasan dan ketidakpuasan melalui beberapa atribut pelayanan yang dijadikan sebagai atribut dalam penelitian. Adapun manfaat yang dapat diberikan dari hasil penelitian ini adalah untuk mengetahui informasi dan bukti secara empiris tentang Kualitas Layanan Sistem Informasi menggunakan Metode Kano dan dapat menggambarkan apakah sistem tersebut sesuai dengan kebutuhan penggunanya, sehingga pihak perpustakaan dapat mengetahui atribut pelayanan mana yang perlu diprioritaskan untuk diperbaiki guna meningkatkan kepuasan pengguna.

\section{LANDASAN TEORI}

\section{A. SISTEM INFORMASI}

Sistem Informasi merupakan sebuah kombinasi yang terorganisasi dari manusia, perangkat keras, perangkat lunak, jaringan komunikasi dan sumber-sumber data yang dikumpulkan, diubah dan informasi yang tersebar dalam suatu organisasi. Menurut Jogiyanto, (2008:11) [3], sistem informasi adalah suatu sistem di dalam suatu organisasi yang mempertemukan kebutuhan pengolahan transaksi harian, pendukung operasi, bersifat manajerial data kegiatan strategi dari suatu organisasi dan menyediakan pihak luar tertentu dengan laporan-laporan yang diperlukan. Dalam arti yang sangat luas, istilah sistem informasi yang sering digunakan merujuk kepada interaksi antara orang, proses algoritmik, data, dan teknologi. Dalam pengertian ini, istilah ini digunakan untuk merujuk tidak hanya pada penggunaan pengorganisasian teknologi informasi dan komunikasi (TIK), tetapi juga untuk, cara di mana orang berinteraksi dengan teknologi ini dalam mendukung proses bisnis.

\section{B. Pengertian, Tujuan, dan Tugas Pokok Perpustakaan}

Pengertian, Tujuan, dan Tugas Pokok Perpustakaan Perpustakaan diartikan sebuah ruangan atau gedung, yang digunakan untuk menyimpan buku dan terbitan lainnya, juga sebagai pusat sumber informasi yang diatur menurut sistem dan aturan yang baku, dan didayagunakan untuk keperluan pendidikan dan penelitian (Basuki, 1991) [4]. Perpustakaan secara umum bertujuan untuk menciptakan masyarakat terpelajar dan terdidik, terbiasa membaca, berbudaya tinggi serta mendorong terciptanya pendidikan sepanjang hayat, dan juga melakukan layanan informasi literal kepada masyarakat. Karena tujuannya memberi layanan informasi literal kepada masyarakat maka tugas pokok adalah:

a.Menghimpun bahan pustaka yang meliputi buku dan nonbuku sebagai sumber informasi.

b.Mengolah dan merawat pustaka.

c.Memberikan layanan bahan pustaka.

\section{Kualitas Layanan}

Definisi yang paling sederhana dari kulitas adalah kesesuaian dengan spesifikasi pengguna. Ide dasarnnya kualitas bukanlah memenuhi sejumlah kriteria yang ditetapkan suatu instansi, sebaliknya kualitas adalah memenuhi kriteria yang ditetapkan oleh pengguna atau pelanggan. Kunci untuk mencapai kulaitas adlah mengetahui siapa pengguna dan apa yang diinginkannya. Kualitas tidak ditentukan oleh satu atribut atau dimensi dari suatu produk atau jasa, tetapi ditentukan oleh beberapa atribut. memperkenalkan subyek kualitas yang diterapkan pada diterapkan pada produk sistem informasi dan telah mengidentifikasi delapan dimensi yang berbeda Raymond( 2007)[1] .

\section{D.Metode KANO}

Metode Kano digunakan untuk mengukur tingkat kepuasan konsumen terhadap kualitas layanan. Dalam Metode kano, menurt (Khamseh, 2011) [2] terdapat 5 kategori faktor kualitas yaitu must be, one-dimensional, attractive, indifference dan reverse yang memiliki karakteristik dan tingkat pengaruh yang berbeda pada konsumen. Di dalam modelnya kano membedakan tiga tipe produk yang diinginkanyang dapat mempengaruhi kepuasan,yaitu (1) Persyaratanyang bersifat must be ( harus ada) merupakan kriteria dasar dari suatu produk. Jika Kategori ini tidak dipenuhi , maka konsumen akan secara ekstrim tidak puas. Karena konsumen manganggap kategori ini sudah semestinya, maka pemenuhan kategori ini tidak akan meningkatkan kepuasan konsumen. (2) Persyaratan yang bersifat one dimensional requirements (Atribut yang diharapkan), pada kategori ini kepuasan konsumen proporsional dengan kinerja atribut. Semakin tinggi kinerja atribut, semakin tinggi pula kepuasa konsumen. Sebaliknya, semakin rendah pemenuhannya maka kepuasan pun akan semakin menurun. Persyaratan one dimensional ini biasanya secara eksplisit diminta oleh pengguna. 
First Wanita, Ashari, Nurpaida - Mengukur Kepuasan Costumer Terhadap Kualitas Layanan Sistem Informasi Perpustakaan Stmik Akba Menggunakan Metode Kano

(3). Persyaratan yang bersifat attractive (menarik), pemenuhan kategori ini akan menyebabkan peningkatan kepuasan konsumen yang sangat tinggi.Tetapi jika tidak ada, tidak akan menyebabkan penurunan tingkat kepuasan.

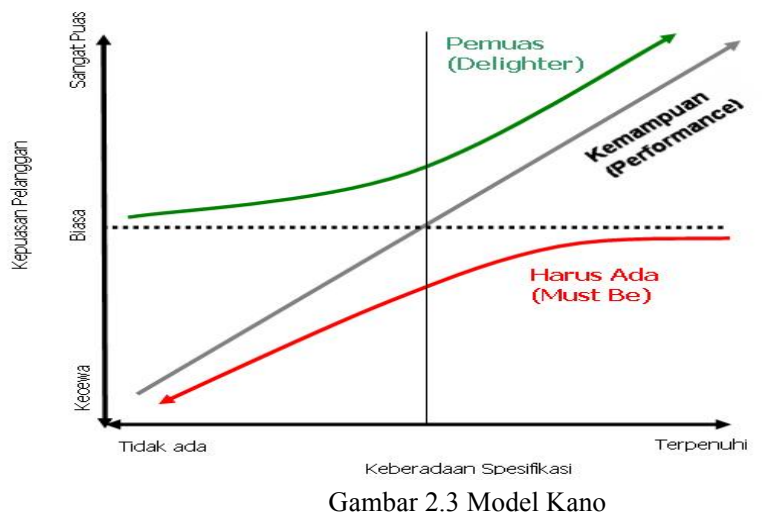

Langkah-langkah penelitian dengan menggunakan Model Kano adalah :

a. Langkah 1 : Identifikasi ide/permintaan pengguna yang akan diukur.

b. Langkah 2 : Membuat Kuesioner Kano

Dalam pembuatan Kuesioner yang perhitungannya menggunakan Model Kano maka sifat dari Kuisioner tersebut adalah setiap satu pertanyaan memiliki dua bagian yaitu functional dan disfunctional.dan pertanyaan, pertanyaan yang telah diuji terlebih dahulu validitas dan reliabilitasnya. Kelima variabel dalam Kano tersebut termasuk skala Likert, karena memiliki gradiasi dari sangat positif sampai sangat negatif.

c. Langkah 3 : Memproses hasil jawaban Kuisioner dengan menggunakan Tabulation of Surveys untuk memproses hasil jawaban Tabel Evaluasi Kano

d. Langkah 4 : Menganalisa hasil proses. Langkah yang dilakukan dengan memposisikan setiap atribut pertanyaan

\section{Desain dan Tahapan Penelitian}

Penelitian ini akan diadakan pada perpustakaan STMIK AKBA adapun prosedur atau tahapan penelitian dimulai dengan studi pendahuluan untuk merumuskan masalah dalam penelitian sehingga dapat ditentukan tujuan dari pelaksanaan penelitian.. tahapan dan disain penelitan dapat di lihat pada gambar di bawah ini

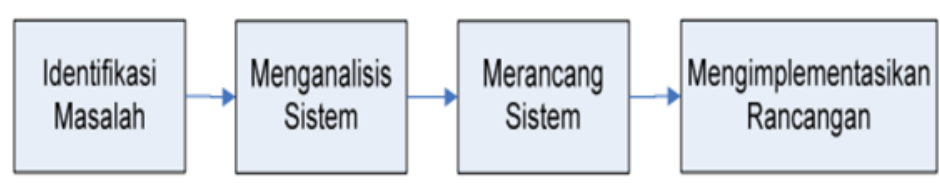

Gambar 3.1 Tahapan penelitian

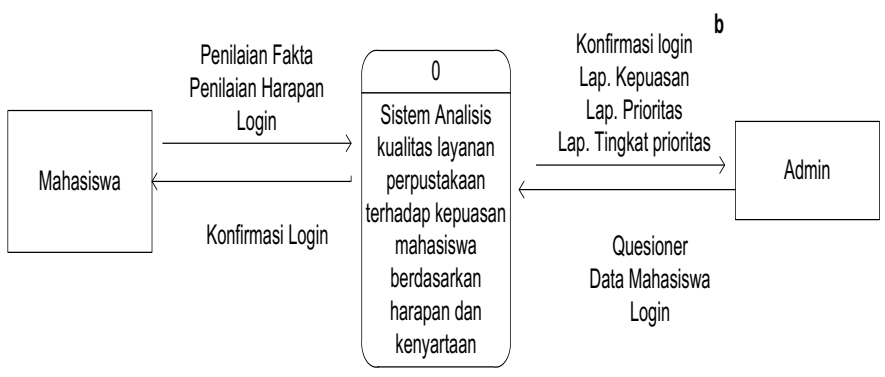

Gambar 3.2 Diagaram Konteks

Membangun sebuah model untuk mengkategorikan atribut pengguna suatu produk atau jasa berdasarkan seberapa baik atribut tersebut dapat memenuhi kebutuhan pengguna. Kategori Kano tentang presepsi kualitas sebagai berikut :

1. Attractive quality elements

Attractive quality elements dapat digambarkan sebagai atribut kejutan dan senag, atribut ini memberikan kepuasan ketika tercapai sepenuhnya, tetapi tidak menyebabkan ketidakpuasan bila tidak terpenuhi. 


\section{One-dimensional quality elements}

untuk kebutuhan pengguna ini, kepuasan pengguna merupakan fungsi linear dari kinerja produk / atribut pelayanan. Kinerja atribut tinggi mengarah kepada kepuasan pengguna yang tinggi.

3. Indifferent quality elements

Indifferent quality elements mengacu pada hal yang tidak baik atau buruk. Kinerja atribut tidak menghasilkan kepuasan atau ketidakpuasan bagi pengguna.

4. Must-be quality element

Untuk kepuasan pengguna ini, pengguna menadi tidak puas ketika kinerja dari produk/jasa rendah. Namun, kepuasan pengguna tidak akan meningkat di atas normal walaupun kinerja dari produk/jasa tinggi.

5. Reverse quality elements

Untuk kebutuhan ini, pengguna menjadi tidak puas ketika kinerja atribut/produk jasa yang tinggi.Hal ini mengacu pada rendahnya prestasi mengakibatkan kepuasan.

Berdasarkan analisis model Kano, variabel-variabel layanan dapat dibedakan menjadi 2 kategori saja, yaitu Must Be dan One Dimensional. Variabel pelayanan yang perlu ditingkatkan adalah kategori One Dimensional karena dengan peningkatan variabel pelayanan tersebut maka kepuasan pengguna akan meningkat pula (linear). Salah satu variabel dalam kategori ini yang perlu ditingkatkan yaitu ketersediaan alat komunikasi dengan pengguna (telepon, sms, faximile, website, email), kelengkapan dan macam alat kalibrator yang dimiliki, jadwal pekerjaan yang tepat waktu, dll. Variabel yang dalam kategori Must Be memang harus diadakan untuk memenuhi kepuasan dasar pengguna, dalam artian pihak pengelola perpustakaan wajib memenuhi hal dasar tersebut sebelum meningkatkan variabel yang lain yaitu One Dimensional. Adapun kategori model kano untuk masing-masing atribut dapat dilihat pada table 3.1

Tabel 3.1 Identifikasi, Definisi dan Indikator Penelitian

\begin{tabular}{|c|c|c|}
\hline Variabel Penilaian & Indikator & Item \\
\hline Tangible & $\begin{array}{l}\text { Aspek-aspek yang } \\
\text { nyata dan dapat dilihat } \\
\text { secara fisik }\end{array}$ & $\begin{array}{l}\text { - } \quad \text { Kelengkapan koleksi buku pada aplikasi } \\
\text { - } \quad \text { Akses internet cepat atau lambat } \\
\text { Hasil Pencarian Buku dapat dilihat/ ditampil- } \\
\text { kan dengan cepat. }\end{array}$ \\
\hline Reliability & $\begin{array}{l}\text { Kemampuan Aplikasi } \\
\text { komputer dalam mem- } \\
\text { berikan informasi }\end{array}$ & $\begin{array}{ll}\text { - } & \text { Aplikasi menampilkan data yang dibutuhkan } \\
\text { - } & \text { Tampilan aplikasi perpustakaan yang menarik } \\
\text { - } & \text { Aplikasi perpustakaan berfungsi dengan baik }\end{array}$ \\
\hline Responsiveness & $\begin{array}{l}\text { Kepedulian petugas } \\
\text { perpustakaan terhadap } \\
\text { pengguna }\end{array}$ & $\begin{array}{l}\text { - Sistem memberikan informasi yang mudah } \\
\text { dimengerti. } \\
\text { - Sisteminformasi perpustakaan memberikan } \\
\text { layanan pencarian data yang cepat, tepat dan } \\
\text { akurat }\end{array}$ \\
\hline Assurance & $\begin{array}{c}\text { Keamanan, dan ken- } \\
\text { yamanan di perpustakaan }\end{array}$ & $\begin{array}{l}\text { - Sistem informasi perpustakaan memberikan } \\
\text { fasilitas penyimpanan data pengguna } \\
\text { - Aplikasi perpustakaan dapat memberikan } \\
\text { kemudahan dalam penggunaannya }\end{array}$ \\
\hline Empathy & $\begin{array}{l}\text { Pemahaman dan per- } \\
\text { hatian kepada pengguna } \\
\text { perpustakaan }\end{array}$ & $\begin{array}{l}\text { - Sistem informasi perpustakaan melakukan } \\
\text { komunikasi yang baik kepada pengguna } \\
\text { - Aplikasi perpustakaan memahami kebutuhan } \\
\text { pengguna perpustakaan } \\
\text { - Apliakasi perpustakaan menampilakn pilihan- } \\
\text { pilihan pembantu kepada pengguna per- } \\
\text { pustakaan. }\end{array}$ \\
\hline
\end{tabular}

\section{B. Metode Pengumpulan Data}

Dalam pengumpulan data sehubungan dengan penulisan ini, metode yang digunakan adalah penelitian lapangan (field research), yaitu penelitian yang dilakukan dengan meninjau langsung tempat yang menjadi objek penelitian. Penelitian tersebut dilaksanakan dengan cara sebagai berikut:

1. Observasi, yaitu metode pengumpulan data berdasarkan pengamatan dan juga pencatatan sistematik atas unsurunsur yang muncul dalam suatu gejala atau gejala-gejala yang muncul di lapangan.

2. Metode pustaka, yaitu metode pengumpulan data yang dilakukan dengan membaca buku-buku, literatur dan jurnal-jurnal yang berhubungan dengan permasalahan yang dibahas dalam laporan.

3. Wawancara, dilakukan secara langsung maupun tidak langsung melalui media komunikasi dengan pihak yang terkait.

\section{Pengukuran Kepuasan Pengguna}


First Wanita, Ashari, Nurpaida - Mengukur Kepuasan Costumer Terhadap Kualitas Layanan Sistem Informasi Perpustakaan Stmik Akba Menggunakan Metode Kano

Kepuasan adalah hasil dari penilaian konsumen bahwa produk atau jasa telah memberikan tingkat kenikmatan dimana tingkat pemenuhan ini lebih atau kurang. Pengguna adalah seseorang yang menggunakan atau memanfaatkan suatu aplikasi atau sistem untuk mencapai tujuan yang diinginkan.

Pada penelitian ini setiap pertanyaan kuesioner kepuasan pengguna dilakukan dengan menggunakan metoda Kano setiap pertanyaan pada kuesioner mahasiswa dengan penilaian kualitatif akan dikuantifikasikan sebagai skor nilai: 4(Baik Sekali), jika semua kinerja mutu setiap standar atau elemen yang diukur sangat baik, 3(Baik), jika semua kinerja mutu setiap standar atau elemen yang diukur baik dan tidak ada kekuranganyang berarti, 2(Cukup), jika semua kinerja mutu setiap standar atau elemen yang diukur cukup, namun tidak ada yang menonjol, 1(Kurang), jika semua kinerja mutu setiap standar atau elemen yang diukur kurang. Penghitungan kepuasan mahasiswa juga dibarengi dengan penghitungan rata-rata harapan mahasiswa sehingga dapat diketahui gap (perbedaan) antar harapan dan kepuasan/fakta.

Gap Analysis = Rerata Fakta - Rerata Harapan (1)

Bila gap positif, maka harapan mahasiswa masih lebih besar bila dibandingkan fakta yang dirasakan. Sementara gap negatif berarti kepuasan yang dirasakan di atas harapan yang diinginkan. Dalam penelitian ini digunakan skala 4 tingkat (Likert) yang dapat dilihat pada table 3.2:

Tabel 3.2 Skala Penilaian
\begin{tabular}{|l|l|l|}
\hline $\begin{array}{l}\text { Kriteria } \\
\text { Fakta }\end{array}$ & Kriteria Harapan & $\begin{array}{l}\text { Sko } \\
\text { r }\end{array}$ \\
\hline Baik Sekali & Baik Sekali & 4 \\
\hline Baik & Baik & 3 \\
\hline Cukup & Cukup & 2 \\
\hline Kurang & Kurang & 1 \\
\hline
\end{tabular}

Pemberian skor untuk masing-masing jawaban bertujuan untuk mempermudah pengolahan data. Berdasarkan hasil penilaian harapan dan hasil pe-nilaian fakta, maka akan dihasilkan suatu perhitungan mengenai nilai rata-rata harapan dan rata-rata fakta. Dalam penelitian ini terdapat dua buah variabel yang diwakilkan oleh huruf X dan Y, di mana X merupakan tingkat kinerja fakta, sedangkan Y merupakan tingkat harapan mahasiswa. Adapun rumus yang digunakan adalah :

$$
\begin{array}{r}
\mathbf{T} \boldsymbol{i}=\boldsymbol{X} \boldsymbol{i} / \mathbf{Y} \boldsymbol{i} \times \mathbf{1 0 0} \% \\
\text { Dimana : Tki : Tingkat Kesesuaian responden } \\
\mathrm{Xi}: \text { Skor Penilaian Fakta sarana prasarana } \\
\text { Yi : Skor Penilaian Harapan Mahasiswa }
\end{array}
$$

Selanjutnya sumbu mendatar (X) akan diisi oleh skor tingkat fakta, sedangkan sumbu tegak (Y) diisi oleh skor tingkat harapan. dalam penyederhanaan rumus, maka untuk setiap faktor yang mempengaruhi kepuasan pengguna dengan :

$$
\bar{X}=\sum X i / n \quad \overline{Y l}=\sum Y i / n
$$

Dimana : X : Skor rata-rata Fakta Y : Skor rata-rata Harapan $\mathrm{n}:$ jumlah responden

\section{HASIL DAN PEMBAHASAN}

\section{A. Uji Coba Sistem}

Untuk mendapatkan hasil yang maksimal, perlu dilakukan pengujian sistem, untuk memeriksa kekompakan atau kinerja antar komponen sistem yang diimplementasikan. Tujuan utama dari pengujian sistem adalah untuk memastikan bahwa elemen-elemen atau komponen-komponen dari sistem telah berfungsi sesuai dengan yang diharapkan.

Pengujian yang digunakan untuk mengukur kualitas layanan Sistem Informasi perpustakaan berdasarkan analisis kualitas layanan perpustakaan terhadap kepuasan costomer (mahasiswa dan dosesn). berdasarkan harapan dan kenyataan menggunakan metode kano ini adalah pengujian Blackbox. Pengujian ini digunakan untuk mengetahui apakah perangkat lunak yang dibangun berfungsi dengan benar dan layak digunakan sesuai yang diharapkan. Adapun komponen-komponen yang akan diuji dalam aplikasiini dapat dilihat pada table 4.1.

Tabel 4.1 Pengujian 
JTIULM - Volume 1, Nomor 2, Juli-Desember 2016: 1-9

\begin{tabular}{|c|l|l|c|c|}
\hline No & \multicolumn{1}{|c|}{ Requirement yang diuji } & \multicolumn{1}{|c|}{ Butir yang diuji } & Actor & Kesimpulan \\
\hline 1 & $\begin{array}{l}\text { Form } \\
\text { (Pengguna) }\end{array}$ & User & ok \\
\hline 2 & Form Login & Melakukan login & Admin, user & ok \\
\hline 3 & Form Hasil Quisioner & $\begin{array}{l}\text { Menampilkan Hasil Perhitungan } \\
\text { Quisioner }\end{array}$ & Admin, user & ok \\
\hline 4 & Form daftar user & Menampilkan form daftar user & Admin & ok \\
\hline 5 & Form input indicator & Menampilkan form input indica- & admin & ok \\
\hline 6 & Form input skala penilaian & Menampilkan form input skala & admin & ok \\
\hline 7 & Form input soal quisioner & Menampilkan form input soal & admin & ok \\
& & quisioner & & Admin, user \\
\hline 8 & Form logout & Keluar dari sistem & ok \\
\hline
\end{tabular}

\section{B. Hasil Perancangan}

Form utama Untuk mengukur kualitas layanan perpustakaan yang akan digunakan dalam system ini adalah sebagai berikut :

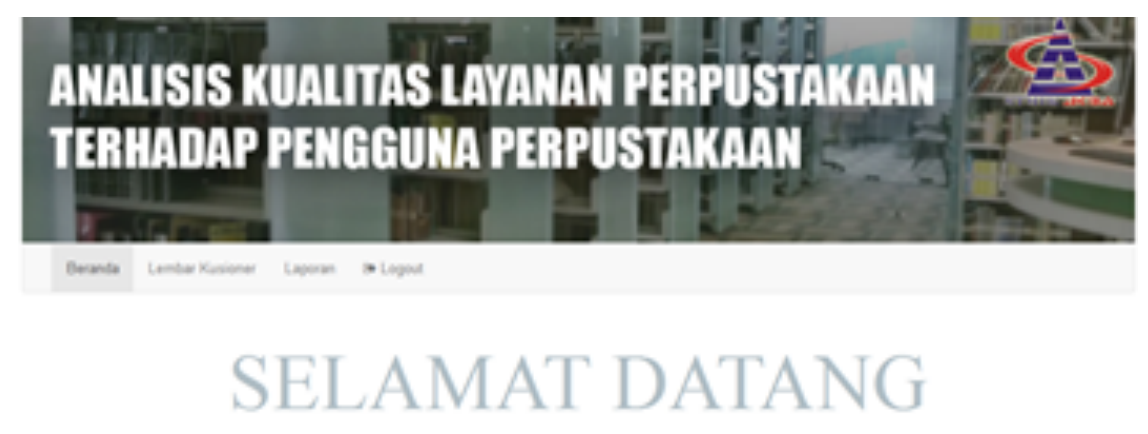

Gambar 4.1 Form utama system pengukuran kualitas layanan

Sementara form untuk mengukur dan menganalisa kualitasa layanana berdasarkan kepuasan dari beberapa costomer (mahasiswa dan dosen), didasarkan pada hasil penilaian quisioner yg diisi oleh mahasiswa atau dosen form kuisoner dapat dilihat pada gambar 4.2. 
First Wanita, Ashari, Nurpaida - Mengukur Kepuasan Costumer Terhadap Kualitas Layanan Sistem Informasi Perpustakaan Stmik Akba Menggunakan Metode Kano

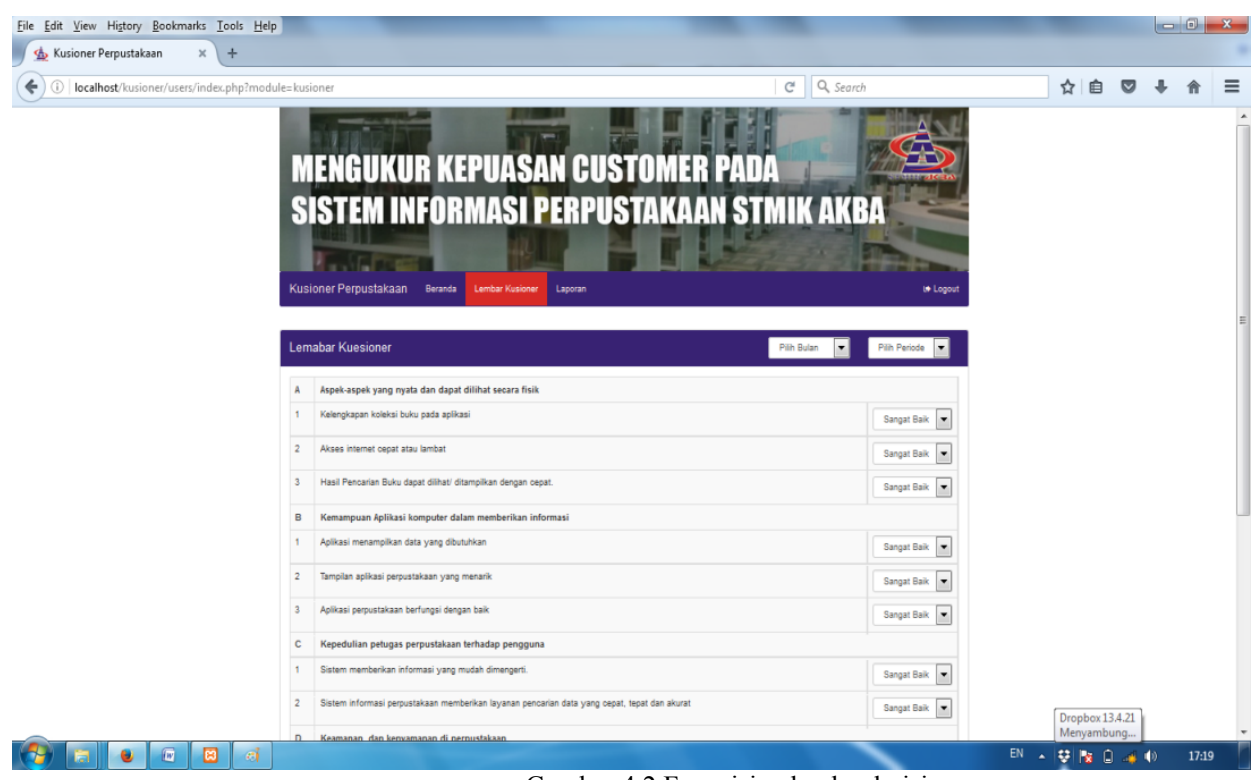

Gambar 4.2 Form isian lembar kuisioner

Selanjutnya program akan menampilkan hasil perhitungan dari tingkat kepuasan dari beberapa pengguna berdasarkan hasil pengisian quisioner dari masing masing responden. Seperti pada gambar 4.3

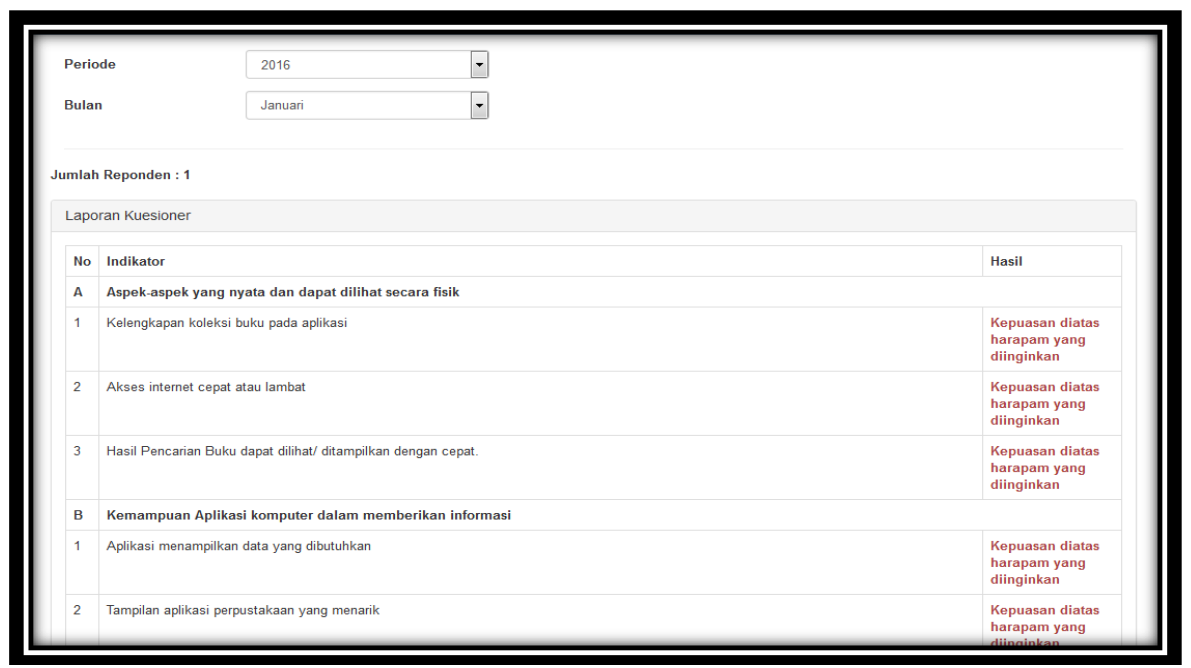

Gambar 4.3 Form Laporan Hasil Survei

\section{Hasil Perhitungan Kuisioner}

Tabel hasil Pengujian dengan sample tiga responden untuk mengukur Sistem Informasi perpustakaan berdasarkan analisis kualitas layanan perpustakaan terhadap kepuasan mahasiswa berdasarkan harapan dan kenyataan menggunakan metode kano, dapat dilihat dari hasil perhitingan kuisoner berdasarkan rata rata fakta dan harapan dan tingkat kesesuaian responden dapat dilihat pada tabel 4.2 .

Tabel 4.2 Hasil Perhitungan Kuisioner

\begin{tabular}{|c|c|c|c|c|c|c|c|c|c|c|}
\hline Soal & $\begin{array}{c}\text { Re- } \\
\text { spond } \\
\text { en 1 }\end{array}$ & $\begin{array}{c}\text { Re- } \\
\text { spond } \\
\text { en 2 }\end{array}$ & \multicolumn{1}{l|}{$\begin{array}{c}\text { Re- } \\
\text { spond- } \\
\text { en 3 }\end{array}$} \\
\hline A & $\mathbf{X 1}$ & $\mathbf{X 2}$ & $\mathbf{X 3}$ & $\begin{array}{c}\text { Rata- } \\
\text { rata } \\
\mathbf{X}\end{array}$ & $\begin{array}{c}\text { Y } \\
\mathbf{1}\end{array}$ & $\mathbf{Y 2}$ & $\mathbf{Y 3}$ & $\begin{array}{c}\text { Rata - } \\
\text { rata } \\
\text { Y }\end{array}$ & $\begin{array}{c}\text { Rerata } \\
\text { nilaiTKi }\end{array}$ & Ket \\
\hline 1 & 4 & 3 & 4 & $\begin{array}{r}3,666 \\
667\end{array}$ & 4 & 4 & 4 & 4 & $91.66 \%$ & $\begin{array}{l}\text { Kepuasan diatas } \\
\text { harapam yang di- } \\
\text { inginkan }\end{array}$ \\
\hline 2 & 3 & 3 & 3 & 3 & 4 & 4 & 4 & 4 & $75 \%$ & $\begin{array}{l}\text { Kepuasan diatas } \\
\text { harapam yang di- } \\
\text { inginkan }\end{array}$ \\
\hline 3 & 3 & 3 & 4 & $\begin{array}{r}3,333 \\
333\end{array}$ & 4 & 4 & 4 & 4 & $83.33 \%$ & $\begin{array}{l}\text { Kepuasan diatas } \\
\text { harapam yang di- } \\
\text { inginkan }\end{array}$ \\
\hline
\end{tabular}




\begin{tabular}{|c|c|c|c|}
\hline \multicolumn{2}{|c|}{ Periode : 2016} & \multicolumn{2}{|l|}{ Bulan : September } \\
\hline \multicolumn{4}{|c|}{ Jumlah Responden : 3} \\
\hline \multicolumn{4}{|c|}{ Skala Penilaian Nilai } \\
\hline \multicolumn{4}{|c|}{ Baik Sekali $\quad 4$} \\
\hline \multicolumn{4}{|c|}{ Baik $\quad 3$} \\
\hline \multicolumn{4}{|c|}{ Cukup $\quad 2$} \\
\hline \multicolumn{4}{|c|}{ Kurang 1} \\
\hline No & & Indikator & Hasil \\
\hline $\mathbf{A}$ & \multicolumn{3}{|c|}{ Aspek-aspek yang nyata dan dapat dilihat secara fisik } \\
\hline 1 & Kelengka & n koleksi buku pada aplikasi & $\begin{array}{l}\text { Kepuasan diatas harapam yang di- } \\
\text { inginkan }\end{array}$ \\
\hline 2 & Akses int & net cepat atau lambat & $\begin{array}{c}\text { Kepuasan diatas harapam yang di- } \\
\text { inginkan }\end{array}$ \\
\hline 3 & $\begin{array}{l}\text { Hasil Pen } \\
\text { dengan ce }\end{array}$ & $\begin{array}{l}\text { rian Buku dapat dilihat/ ditampilkan } \\
\text { t. }\end{array}$ & $\begin{array}{c}\text { Kepuasan diatas harapam yang di- } \\
\text { inginkan }\end{array}$ \\
\hline B & \multicolumn{3}{|c|}{ Kemampuan Aplikasi komputer dalam memberikan informasi } \\
\hline 1 & \multicolumn{2}{|c|}{ Aplikasi menampilkan data yang dibutuhkan } & $\begin{array}{c}\text { Kepuasan diatas harapam yang di- } \\
\text { inginkan }\end{array}$ \\
\hline 2 & \multicolumn{2}{|c|}{ Tampilan aplikasi perpustakaan yang menarik } & $\begin{array}{c}\text { Kepuasan diatas harapam yang di- } \\
\text { inginkan }\end{array}$ \\
\hline 3 & \multicolumn{2}{|c|}{ Aplikasi perpustakaan berfungsi dengan baik } & $\begin{array}{c}\text { Kepuasan diatas harapam yang di- } \\
\text { inginkan }\end{array}$ \\
\hline $\mathbf{C}$ & \multicolumn{3}{|c|}{ Kepedulian petugas perpustakaan terhadap pengguna } \\
\hline 1 & \multicolumn{2}{|c|}{$\begin{array}{l}\text { Sistem memberikan informasi yang mudah di- } \\
\text { mengerti. }\end{array}$} & $\begin{array}{c}\text { Kepuasan diatas harapam yang di- } \\
\text { inginkan }\end{array}$ \\
\hline 2 & \multicolumn{2}{|c|}{$\begin{array}{l}\text { Sistem informasi perpustakaan memberikan layanan } \\
\text { pencarian data yang cepat, tepat dan akurat }\end{array}$} & $\begin{array}{c}\text { Kepuasan diatas harapam yang di- } \\
\text { inginkan }\end{array}$ \\
\hline $\mathbf{D}$ & \multicolumn{3}{|c|}{ Keamanan, dan kenyamanan di perpustakaan } \\
\hline 1 & \multicolumn{2}{|c|}{$\begin{array}{l}\text { Sistem informasi perpustakaan memberikan fasilitas } \\
\text { penyimpanan data pengguna }\end{array}$} & $\begin{array}{c}\text { Kepuasan diatas harapam yang di- } \\
\text { inginkan }\end{array}$ \\
\hline 2 & \multicolumn{2}{|c|}{$\begin{array}{l}\text { Aplikasi perpustakaan dapat memberikan kemudahan } \\
\text { dalam penggunaannya }\end{array}$} & $\begin{array}{l}\text { Kepuasan diatas harapam yang di- } \\
\text { inginkan }\end{array}$ \\
\hline $\mathbf{E}$ & \multicolumn{3}{|c|}{ Pemahaman dan perhatian kepada pengguna perpustakaan } \\
\hline 1 & \multicolumn{2}{|c|}{$\begin{array}{l}\text { Sistem informasi perpustakaan melakukan komu- } \\
\text { nikasi yang baik kepada pengguna }\end{array}$} & $\begin{array}{c}\text { Kepuasan diatas harapam yang di- } \\
\text { inginkan }\end{array}$ \\
\hline 2 & \multicolumn{2}{|c|}{$\begin{array}{l}\text { Aplikasi perpustakaan memahami kebutuhan } \\
\text { pengguna perpustakaan }\end{array}$} & $\begin{array}{c}\text { Kepuasan diatas harapam yang di- } \\
\text { inginkan }\end{array}$ \\
\hline 3 & \multicolumn{2}{|c|}{$\begin{array}{l}\text { Apliakasi perpustakaan menampilkan pilihan-pilihan } \\
\text { pembantu kepada pengguna perpustakaan. }\end{array}$} & $\begin{array}{c}\text { Kepuasan diatas harapam yang di- } \\
\text { inginkan }\end{array}$ \\
\hline
\end{tabular}


First Wanita, Ashari, Nurpaida - Mengukur Kepuasan Costumer Terhadap Kualitas Layanan Sistem Informasi Perpustakaan Stmik Akba Menggunakan Metode Kano

\section{KESIMPULAN}

Berdasarkan penelitian yang telah dilakukan selama proses perancangan hinggga implementasi Sistem pengkuran kuaIitas layanan system informasi perpustakaan berdasarkan analisis kualitas layanan perpustakaan terhadap kepuasan costumer berdasarkan harapan dan kenyataan menggunakan metode kano, maka dapat diambil kesimpulan sebagai berikut:

1. Aplikasi pengukuran kualitas layanan sistem informasi perpustakaan berdasarkan analisis kualitas layanan perpustakaan terhadap kepuasan mahasiswa dan dosen berdasarkan harapan dan kenyataan menggunakan metode kano, dinyatakan layak digunakan karena melihat hasil persentasi pada aspek-aspek pengujian tingkat kesesuaian terhadap reponden $(\mathrm{TKi}) \geq 75 \%$ memeberikan respon yang baik..

2. Atribut yang menjadi prioritas dalm perbaikan terdiri dari aspek-aspek nyata dan dapat dilihat secara fisik, kemampuan aplikasi dalam memberikan informasi, kepedulian petugas terhadap pengguna keamanan dan ketertiban di perpustakaan.

Saran pada penelitian yang dilakukan tentunya tidak terlepas dari kekurangan dan kelemahan. Oleh karena itu, untuk kebaikan pengembangan sistem lebih lanjut, maka penulis menyarankan beberapa hal diantaranya :

1. Dikarenakan ilmu pengetahuan terus berkembang dan ditemukan hal-hal baru maka indikator dan soal dari penilaian evaluasi sistem informasi perpustakaan ini perlu di update atau ditambah, sehingga data-data yang ada menjadi lebih lengkap dan complex

2. Untuk mendapatkan hasil perhitungan kuisioner yang lebih baik lagi perlu penamabahan jumlah responden.

\section{DAfTAR Pustaka}

[1] Mc Leod Raymond, 2007. Management Information Systems/ 10th.ed., Upper Saddle River : Pearson Education

[2] Khamseh, Arshadi. 2011. Integrating Kano's Model into QFD to Optimally Identify and Prioritize the Needs of Higher Education. Institute of Interdisciplinary Business Research

[3] Jogiyanto, HM. 2008 Sistem Teknologi Informasi Yogyakarta: Andi

[4] Basuki, Sulistyo. 1991. Pengantar Ilmu Perpustakaan. Jakarta: Gramedia Utama.

[5] Fattah, Hanif A1.2007.Analisis dan Perancangan Sistem Informasi untuk keunggulan bersaing Perusahaan dan Organisasi modern . Yogyakarta : Andi

[6] Nugroho, B.2004.PHP \& MySQL dengan editor Dreamever MX.

[7] Hiadayat,Rahmat. 2010.Cara Praktis Membangun Website Gratis 